\title{
Selvmord og borderline personlighetsforstyrrelse
}

\author{
Unn Tjelflaat intervjuer Otto Kernberg
}

\author{
- Jeg går ut nødutgangen. Når krisen er total og døden forfører og paralyserer meg. Når jeg \\ opplever et voldsomt sinne og vil hevne meg. Da brenner jeg meg. Eller går ut nødutgangen. \\ Psykoanalytiker Otto Kernberg gav et noenlunde slikt bilde av den indre verden hos en \\ selvmordstruet person med borderline personlighetsforstyrrelse. Vi traff ham under \\ Schizofrenidagene i Stavanger 9. - 11. november 2005.
}

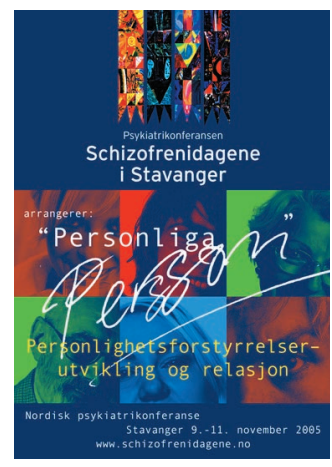

- Kan du si noe om den indre verden hos en selvmordstruet med borderlinepersonlighet?

- Det vil dypest sett være en opplevelse som bare den selvmordstruede personen selv har tilgang til. Vi er henvist til å se den og beskrive den utenfra. Likevel vet vi noe om personens indre verden, framholder Kernberg.

\section{Krise og hevn}

Han forklarer at personer med borderline personlighetsforstyrrelse kan være både selvskadere og selvmordere. I tillegg peker han på to ulike former for atferd f $\varnothing \mathrm{r}$ et selvmordsfors $\varnothing \mathrm{k}$.

- Den typiske borderlineatferden er preget av store følelsesmessige svingninger og spenninger. Før et selvmord kan disse nå et klimaks og gå over i krise. Men personer med borderline personlighetsforstyrrelse kan også være kjølig beregnende og hemmelighetsfulle. De kan ha en slags lystfølelse og være forf $\varnothing r t$, ja totalt paralysert av tankene på selvmordet. Og de kan også føle seg aggressive og oppleve at vreden er lystbetont. Tanken på selvmord kan da være en slags triumferende lyst, en hevn over verden. Men da snakker vi om narsissistiske trekk.

En person med borderline kan oppleve voldsomme og dramatiske indre opplevelser. De kan stige til et så intenst raseri inne i sin egen kropp, at døden synes som en befrielse, en lettelse og en glede. $\mathrm{Da}$ vil det å kutte seg, brenne seg med en sigarett eller rispe seg føles som en vei ut av den indre smerten. I slike tilfeller er selvmordsfors $\varnothing$ ket eller selvskadingen utført for å begrense seg selv og sin kropp. Men dette har ingen sammenheng med depresjon, forteller Kernberg.

\section{Intens aggresjon}

Slike dramatiske opplevelser inntrer ofte akutt og momentant. Motivet kan

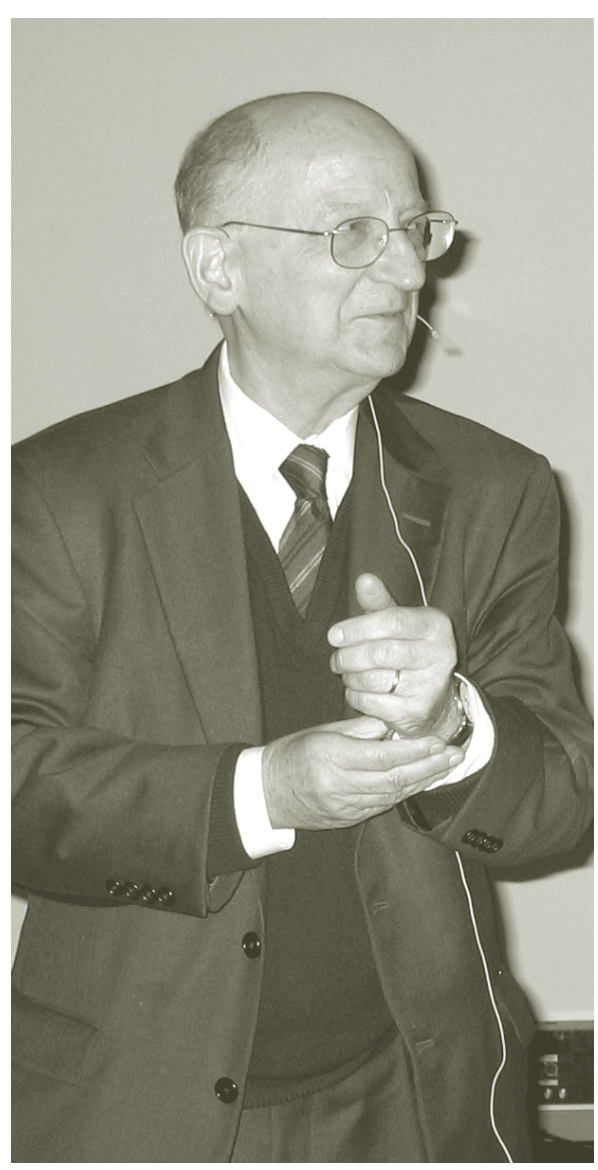

være både en hevnakt og det å slippe unna alvorlige konflikter. Eller det kan være et behov for å ta kontroll over andre.

- Ofte er det foreldrene. Nå behøver de unge ikke lenger å være redde for foreldrenes fors $\varnothing \mathrm{k}$ på kontroll over dem. Men det kan også være et ekstremt fors $\varnothing \mathrm{k}$ på å imponere. Samtidig kan drivkraften være et rop om hjelp kombinert med en aggressiv demonstrasjon av verdens ondskap. Vi har med andre ord å gjøre med en intens aggresjon.

\section{Hat - kjærlighet}

Kernberg viser til selvmordet som eksistensiell opplevelse.

- På et dypere nivå vil selvmordet i denne sammenheng være et uttrykk for en identifikasjon med et fiendeobjekt og offer på samme tid. Som negativ kvinne og mor i ett. Som provoserende, fiende - mor og omsorg - mor. Hat - kjærlighet. Identifikasjonen skjer på et ubevisst plan. Dette tegner et sadomasochistisk bilde.

\section{Døden er befrieren}

Kernberg snakker om ulike opplevelser hos deprimerte og ikke-deprimerte.

- Vi har sett at lysten til eller behovet for triumf kan være en drivkraft hos personer med borderline. "Jeg klarer ikke virkeligheten, jeg vil bort. Jeg går ut nødutgangen", er drivkraften bak denne type selvmordsatferd. Men dette er forskjellig fra det som ligger bak hos de dypt deprimerte. Da snakker vi om en intens følelse av ensomhet og forlatthet, en fryktelig smerte. Men borderlinepersoner føler seg ofte vel ved tanken på selvmord. Døden er befrieren fra spenning og frykt og umulige relasjoner, forklarer han.

\section{Behandling}

Kernberg peker på to ulike behandlinger for selvmordstruede personer med borderline personlighetsforstyrrelser. I tilfeller med dyp depresjon er den mest egnede behandlingen medisinsk psykoterapi. Uten depresjon er det nødvendig å behandle selve borderline-personligheten. Det gjelder både borderline med og uten narsissistiske trekk.

- Psykoanalytisk psykoterapi (TFP) er den eneste metoden som fanger opp den totale og hele personligheten. Psykoterapi og kognitiv psykoanalyse (DBT) behandler kun symptomer, slår den kjente psykoanalytikeren fast.

Selvmordstallene for borderline personlighetsforstyrrelser er 5-9 \% uten eller med ikke-adekvat behandling. Med behandling er disse tallene redusert til 1-2 \%, avslutter Otto Kernberg.

Unn Tjelflaat er barnevernspedagog og frilansjournalist. 